\title{
Introduction to Translation and Deterritorialization
}

\author{
Karen Van Dyck
}

I originally intended a portion of this volume on translation to address the shared theoretical concerns and shared practices of translation and women's writing in Greece. Reading through the abstracts I received I was prompted to reconsider the orientation. Though women's writing was a pivotal metaphor for many, the common denominator was the marginal status of various writing, not just women's, in the already minor literature of modern Greek. The issue of JMGS on minor literature was not published when this set of articles was written, but the questions raised there provide a crucial introduction to the more specialized topic of translation and minor literature explored here. The abstracts of articles addressed a range of discourses from women's writing to homosexual poetry, to slang in rébetika, to prose as a minor genre in Greece. Perhaps the comparison between translation and one minor discourse, women's writing, was too neat an organizing principle. A more productive approach might emphasize the co-implication of translation and various minor literatures and address some of the shared theoretical and practical concerns of translating a women's text, a homosexual poem, slang, or a minor genre in an already minor literature. If, as my own work had led me to suppose, women's writing had become one of the more dynamic sites of minor literature in the $1980 \mathrm{~s}$ in Greece, this could be more fruitfully discussed in the context of a general discussion which drew on others' expertise.

In order to focus the debate I suggested that panelists read Gilles Deleuze's and Félix Guattari's chapter entitled "What is a Minor Literature?" in their book, Kafka: Towards a Minor Literature (1986). The appropriateness of this particular theory of minor literature to the case of modern Greek literature is extensively debated in the last issue of JMGS. Since a few articles refer to this argument $I$ will begin by briefly outlining what Deleuze and Guattari mean by minor literature,

Journal of Modern Greek Studies, Volume 8, 1990. 
and how I think this might be useful to a discussion of translating modern Greek literature. According to Deleuze and Guattari a minor literature "doesn't come from a minor language, it is rather that which a minority constructs within a major language" (1986: 16), the Jewish literature of Warsaw and Prague, for example. A distinguishing characteristic of minor literature is its high coefficient of what these authors call deterritorialization. This term is applied to various things over the course of their book: languages, writing styles, literary tropes, but it always has to do with the foreigness of something. In the case of Kafka it has to do with the fact that the language he writes in, PragueGerman, is not Czech, his mother tongue and with the fact that this Prague-German is a bureaucratic language, a "paper language." Deleuze and Guattari contrast the way Kafka accentuates deterritorialization by accepting Prague-German in all its poverty while othersGustav Meyrink, Max Brod-choose to embellish Prague-German "through all the resources of symbolism, of oneirism" (1986: 19). They point out that Kafka's sober further deterritorialization and Meyrink's and Brod's excessive reterritorialization highlight deterritorialization; they simply do it in different ways. In Ireland, they add, a similar contrast might be made between the symbolically sparse writing of Beckett and the symbolically swollen writing of Joyce.

The particular Greek case, however, demands further specifications. Before we can discuss translation and minor literatures in Greece, it is necessary to frame such a discussion within the context of modern Greek literature's own minor status. Modern Greek literature is not minor because only twenty million people speak Greek; it is minor because it is considered minor in the context of something major. What is obvious from Solomos to Seferis is that modern Greek literature has been constructed and has constructed itself in the shadow of a major classical language: ancient Greek. Modern Greek's deterritorialized status is all too familiar to those of us who are continually asked to distinguish our work from that of the Classicist"no," we say, "modern Greek." And when Greek is given the status of a modern European language it is invariably compared to "major" European languages such as English, French and German. The already deterritorialized nature of modern Greek literature, therefore, must be kept in mind as we open discussion to various cases of translating minor literature within Greek literature.

The following five papers in very different ways analyze connections between translation and deterritorialized writing. First I discuss how the concept of deterritorialization is useful in analyzing contemporary women's poetry, its translation and translation more generally. Gail Holst then addresses the difficulties of translating slang 
in Rebétika. Peter Bien compares various translations of Cavafy's poetry in order to illustrate the importance of his homosexual readership. Helen Kolias returns us to the topic of women's writing, this time in a discussion of translating women's autobiography. And Irene Kacandes concludes this section by addressing the question of translating second person references in the minor genre of prose. ${ }^{1}$

Columbia University

\section{NOTE}

${ }^{1}$ I want to thank William Spanos for responding to earlier drafts of all these papers when they were read at the MLA in December 1989. 